地方都市における気象マップの作成と都市気候の実態に関する研究

\title{
A STUDY ON THE DRAWING OF WEATHER MAPS AND THE ACTUAL CONDITIONS OF THE URBAN CLIMATE IN A PROVINCIAL CITY
}

\author{
岩井一博*1, 高木直樹*2, 浅野良晴*3, 山下恭弘*3 \\ Kazuhiro IWAI, Naoki TAKAGI, Yoshiharu ASANO \\ and Yasuhiro YAMASHITA
}

\begin{abstract}
In order to research the actual conditions of the urban climate in Nagano City, weather maps were made by drawing with temperature and relative humidity data.

The authors obtained the following results:

(1) Weather maps were made by drawing at an optional season, time and weather condition. For example, they were constructed at the coldest day and the hottest day, and they were examined for error, too.

(2) A similarity in character of temperature in the commercial district in Nagano City and Matsumoto City was confirmed. As a result, the commercial district in these cities was different from the climate of the major city.
\end{abstract}

Keywords : urban climate, weather map, land use, provincial city, AMeDAS, Nagano City

都市気候，気象マップ，土地利用，地方都市，アメダス，長野市

1. はじめに

建物の設計を行う上では、当該建設地の気象状況を把握しておく 事が重要である。例えば、建物の熱負荷シミュレーション計算や有 効なパッシブ手法を検討する場合は、その地点の具体的な気象デー タが必要となる。しかしながらその様な検討の際は、一般的に当該 地点に最も近い気象台のデータや、標準気象データを用いる事が多 く、そのデータが必ずしも現地に対応していないケースが見られる。 一方、近年において AMeDAS が整備され、気温、降水量、日照 時間、風向風速の観測が行われているが、未だ十分な細かさとは言 えない場合がある。比較的狭い範囲に土地利用の違いがある場合に は、その地点毎に微気象が存在するため、それを考慮した気象デー タが必要である。

この様な背景により、本研究者らはAMeDAS の観測網より狭い 領域を対象とし、実測值を用いた気象マップの作成を試みた。

既に報告されている気象マップの一例として、武政ら ${ }^{1)}$ や玉ら 2) は建策設計用地域気候マップを作成し、冬期における日本全体の 気温や日射量の実態を明らかにしている。また、西川ら ${ }^{3)}$ は九州地 方を対象に、各種気象データを用いて自然エネルギー活用のための
気象マップを作成している。吉田 ${ }^{4)}$ は近畿地方を対象に、気象デー タのモデル化により都市気候を明らかにしている。この他、気象デ

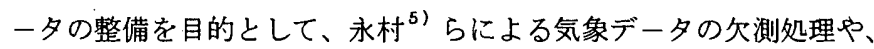
二宮 ${ }^{6)}$ らによる大気放射量の推定、石野 ${ }^{7)}$ らによる空調設計用外 気温度の作成などの研究が報告されている。

こうした一連の研究により、国内各地の気象データやその特性に ついて究明する事が可能となった。

しかし、これらの報告は比較的広い領域を扱うため、AMeDASの 観測網である約 $21 \mathrm{~km}$ 四方より狭い領域については、必ずしも十分な データとは言えない場合がある。特に気温や相対湿度は、土地利用 の違いにより值が異なるため、詳細な観測データが必要である。そ のため、本研究者らは数十 km四方を対象に、地域内における気温と 相対湿度の実測值に基づく気象マップの作成を行った。対象地域は、 多種多様な土地利用が存在する長野市を選定した。当該地域は、冬 季オリンピックを契機に土地利用の変化が予想され、今後の都市計 画を進める上でも現状を明らかにしておく事が必要と考える。また、 地方の都市気候の実態を明らかにし、大都市との違いを知る上でも 有効であると考える。

\footnotetext{
${ }^{* 1}$ 信州大学工学部社会開発工学科 技術専門職員

*2 信州大学工学部社会開発工学科 助教授 $\cdot$ 工博

*3 信州大学工学部社会開発工学科 教授 $\cdot$ 工博
}

Engineer, Dept. of Architecture and Civil Engineering, Faculty of Eng., Shinshu
Univ.
Assoc. Prof., Dept. of Architecture and Civil Engineering, Faculty of Eng., Shinshu
Univ., Dr. Eng.
Prof., Dept. of Architecture and Civil Engineering, Faculty of Eng., Shinshu Univ.,
Dr. Eng. 
よって、本論文では長野市における気温と相対湿度の実測を行い、 地域内の気象マップを作成し、その都市気候を明らかにする。また 作成した気象マップより特に中心商業地域を取り上げ、気温の実態 について検討を行う。そのため、同一性の検証に基づく研究対象地 域の確定、対象地域内における気温と相詨湿度のマップの作成、気 象マップの500inッシュ内の土地利用が混在する場合の誤差、商業 地域における冬期と夏期の気温特性の各項目について検討を行う。 この結果が、建物の熱負荷シミュレーション計算や有効なパッシブ 手法の検討のための资料となる事を研究目標とする。

\section{2. 既報の研究内容と本研究の位罝づけ}

本研究者らによる既報 ${ }^{8)}$ の研究内容について整理する。図一1に そのフローチャートを示す。

既報では、始めに長野市の気象を他の都市と比較する事により、 その特性を明らかにした。そして、その様な気象特性を持つ対象地 域を500m $\times 500 \mathrm{~m}$ のメッシュで470点に分割し、気象台を定点とした 移動測定を行い、そのデータをクラスター分析によりグループ化し た。次に、各グループの気象データは土地利用と相関があると仮定 し、土地利用每に代表点を選定して気温と相対湿度の連続測定を行 い、時系列変化を観測した。また、土地利用が均一である500mメッ シュ内の微気象を知るため、内部を $100 \mathrm{~m}$ メシュで分割し、中央点 （代表点）と分割した他の点について、気温と相対湿度の同一性を 検証した。最後に、代表点で得られたデータの対象地域内における 土地利用毎の代表性を検証し、対象地域内では土地利用が等しい場 合、気温と相対湿度は信頼度95\%でほぼ一致する事を明らかにした。 次に、本論文の研究内容について整理する。図－2にそのフロチャートを示す。

既報 ${ }^{8)}$ では、対象地域内において土地利用が等しい場合は、気温 と相対湿度は信頼度 $95 \%$ でほぼ一致する結果が得られた。本論文で はここで得られたデータを使用し、当該地域の気温と相対湿度の分 布を明らかにする。また、既報で問題とした中心商業地域の気温に ついても検討を行う。その手順として、始めに対象地域外にあたる 飯山市から坂城町までの計 6 点の気象を観測し、同一のデータとし て取り扱う事が可能な範囲を明らかにしている。次に、土地利用に 基づく対象地域の気温と相対湿度の時系列での気象マップを作成し、 併せてその誤差について検討している。そして、作成した気象マッ

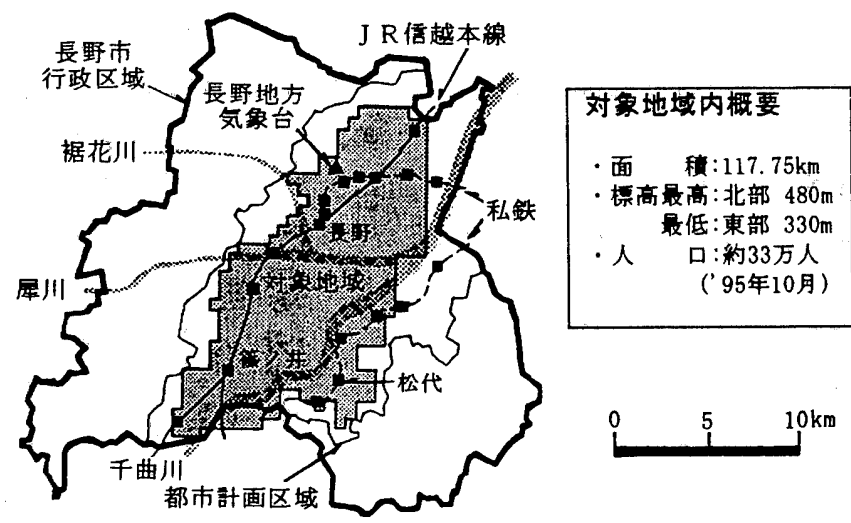

図ー3 研究の対象地域

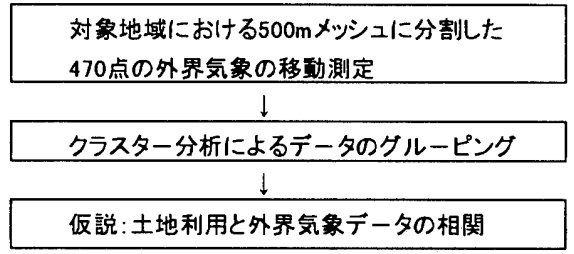

$\downarrow \quad[$ 時系列変化の梘測 $]$

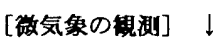

土地利用が均一な $500 \mathrm{~m}$
メッシュ内の気温と相対
湿度を $100 \mathrm{~m}$ 毎に測定

湿度を $100 \mathrm{~m}$ 毎に測定

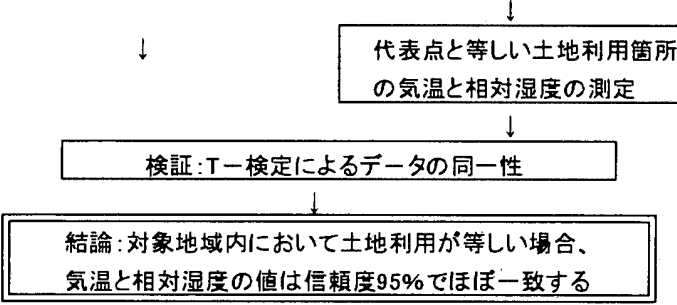

\section{図ー1 本研究者らによる既報の研究内容}

既報の結論 : 対象地域内において土地利用が等しい场

合、気温と相対湿度の値は信頼度 $95 \%$ でほぼ一致する

$\cdot 4$ 章

. 5 章 1 項

.5章2項

.5章3項

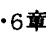

· 7 章 目2 本論文の研究内容

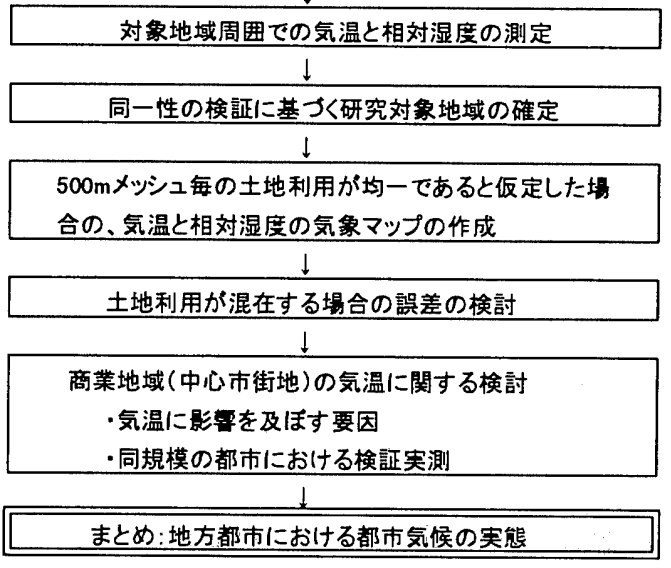




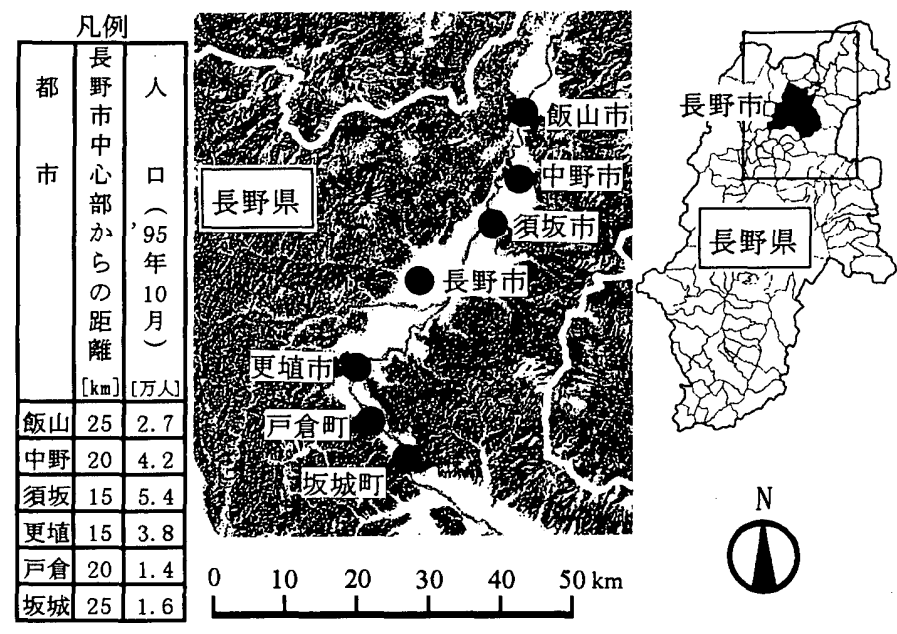

図-5 対象地域周囲の検証点の位置図

プより都市の中心部にあたる商業地域に着目して、冬期と夏期の気 温の実態について検討している。ここでは気温に影響を及ぼす要因 として、周辺の建物や地面の表面温度を取り上げる。また、長野市 と同規模の都市の松本市を対象にして同様の測定を行っている。こ れらをまとめて、対象地域の都市気候の実態を明らかにしている。

\section{3. 対象地域及び測定方法}

本論文では、図ー 3 に示す領域を研究対象とする。対象地域は、 長野市内の DID 地区を含的た都市計画区域内の $500 \mathrm{~m}$ メッシュで分割 した470点である。図ー4に連続測定を行っている代表点の概要を それぞれ示す。各代表点は何れも土地利用に基づいて選定しており、 それぞれ、公園、商業、中層住宅、低層住宅、果樹農家と呼称寸る。 各代表点では、何れもの印の地面より $1.5 \mathrm{~m}$ 高さの地点において、 ’96年12月より10分毎の瞬時值の記録を開始し、現在も測定を継続 している。使用した測定器は、温度がサーミスタ式で相対湿度が高 分子型である。なお、測定点の選定方法は500mメッシュ内の土地利 用を代表する中央付近とし、測定器に直射日光が当たらず、建物か ら1m以上㒕れた場所とした。

\section{4. 対象地域周囲におけるデータの同一性の検証}

対象地域に㧍ける土地利用が等しい場合の、気温と相対湿度のデ 一タの同一性については既報 ${ }^{8)}$ で検証済みである。

一方、データの同一性は、本来は行政区域の境界で区分するので はなく、同一のデータとなる範囲を明らかにし、その領域を共通の データとして扱う事が望ましい。従って、土地利用の中の低層住宅 を取り上げ、対象地域の周囲より検証点を選出して、代表点との同 一性について検定を行った。

対象地域周囲となる飯山市から坂城町までの検証点の位置を図一 5 に示す。これらの地点は何れも一連の盆地内に位置し、長野市の 中心部からのおよその距離は、北部と南部にそれぞれ $15 \mathrm{~km}, 20 \mathrm{~km}, 25$ $\mathrm{km}$ とっている。

検証方法は、先に選出した代表点と対象地域周囲の検証点で同時 測定を行い、両者のデータについてTー検定を行った。解析には ’ 97 年10月〜11月の間における晴天日の 3 日間より、毎正時の 72 デ
表一 1 代表点と検証点の概要と検証結果

\begin{tabular}{|c|c|c|c|c|c|c|c|c|c|}
\hline & \multirow{2}{*}{$\begin{array}{l}\text { 標 } \\
\text { 高 } \\
\text { [m] }\end{array}$} & \multicolumn{2}{|c|}{$\begin{array}{c}\text { 形態规制 } \\
{[\%]^{1)}}\end{array}$} & \multicolumn{3}{|c|}{$\begin{array}{c}500 \mathrm{~m} x_{\text {ッシュ内の }} \\
\text { 面樌率 }[\%]^{2)}\end{array}$} & \multicolumn{2}{|c|}{$\begin{array}{l}\mathrm{T} \text {-検定による } \\
\text { 基準点との比較 }{ }^{3)}\end{array}$} \\
\hline & & & $\begin{array}{l}\text { 容 } \\
\text { 積 } \\
\text { 蘶 }\end{array}$ & $\begin{array}{l}\text { 建へ } \\
\text { w率 }\end{array}$ & $\begin{array}{l}\text { 建 } \\
\text { 物 } \\
\text { 率 }\end{array}$ & $\begin{array}{l}\text { 敷 } \\
\text { 地 } \\
\text { 率 }\end{array}$ & $\begin{array}{l}\text { 道 } \\
\text { 路 } \\
\text { 率 }\end{array}$ & $\begin{array}{l}\text { 気 } \\
\text { 温 }\end{array}$ & $\begin{array}{l}\text { 相対 } \\
\text { 湿度 }\end{array}$ \\
\hline \multicolumn{2}{|c|}{ 代表点 } & $\overline{415}$ & $\overline{880}$ & $\overline{50}$ & $\overline{22}$ & $\overline{54}$ & 24 & $\overline{-}$ & - \\
\hline \multirow{6}{*}{$\begin{array}{l}\text { 対 } \\
\text { 象 } \\
\text { 地 検 } \\
\text { 域 証 } \\
\text { 周 点 } \\
\text { 囲 }\end{array}$} & 飯山市 & $\overline{363}$ & 80 & 50 & 30 & $\overline{42}$ & 28 & $\bar{x}$ & $\bar{x}$ \\
\hline & 中野市 & 358 & $\pi$ & "I & 38 & 43 & 19 & 0 & $\bar{x}$ \\
\hline & 湏坂市 & 370 & "I & 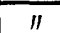 & 39 & 46 & 15 & $x$ & $\bar{x}$ \\
\hline & 更填市 & 362 & $"$ & $" 1$ & 27 & 58 & 15 & $x$ & $\bar{x}$ \\
\hline & 戸倉町 & 373 & $\pi$ & $"$ & 23 & 54 & 23 & $x$ & $x$ \\
\hline & 坂城町 & 390 & $\pi$ & $\pi$ & 25 & 51 & 24 & $\bar{x}$ & $\bar{x}$ \\
\hline \multirow{5}{*}{$\begin{array}{l}\text { 詨 } \\
\text { 象 検 } \\
\text { 地 証 } \\
\text { 域 点 } \\
\text { 内 }\end{array}$} & $\overline{\mathrm{t1}}$ & $\overline{404}$ & $\overline{80}$ & $\overline{\overline{50}}$ & $\overline{222}$ & $\overline{51}$ & $\overline{277}$ & $\overline{0}$ & $\overline{\bar{o}}$ \\
\hline & $\overline{t 2}$ & 407 & $\pi$ & $\pi$ & 27 & 44 & 29 & 0 & 0 \\
\hline & t3 & 403 & $\pi$ & "I & 25 & 41 & 34 & 0 & 0 \\
\hline & $\mathrm{t} 4$ & 396 & $\pi$ & 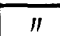 & 32 & 45 & 23 & 0 & $\bar{x}$ \\
\hline & t5 & 369 & $" 1$ & 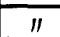 & 36 & 49 & 15 & 0 & 0 \\
\hline
\end{tabular}

注 1) 平成8年度における各地域の都市計画図に基づく

注 2) 全体 $(100 \%)$ 上り建物率と道路率を除いた値

注 3) ○は信頼度95\%で同一と判断されたもの

メは倍頼度95\%で同一ではないと判断されたもの
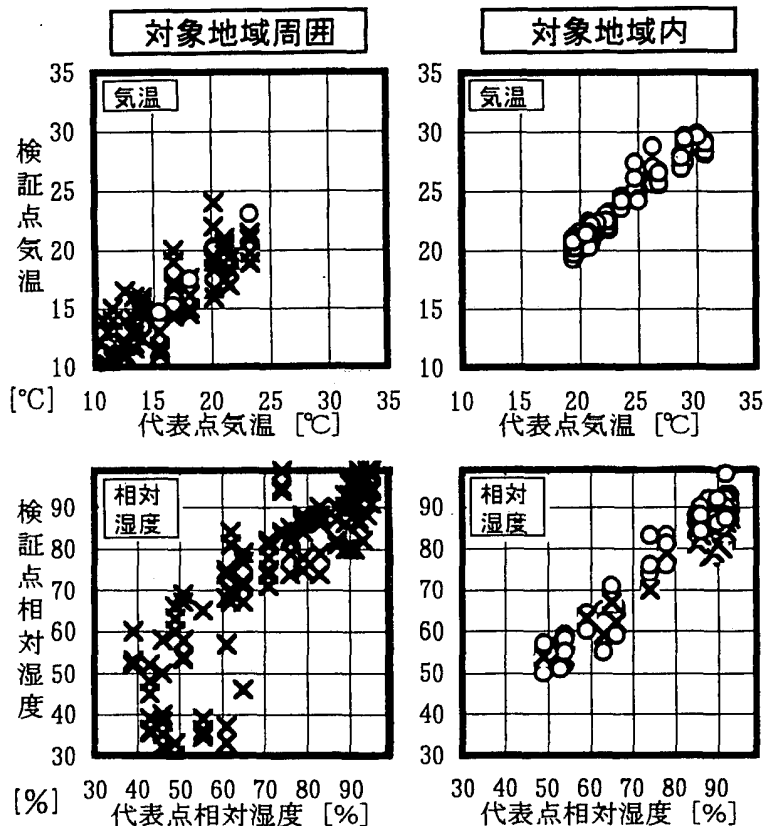

凡 例 O: 信頼度95xで同一と判断されたもの

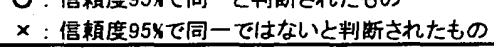

図一6 代表点と検証点における気温と相対湿度の比較

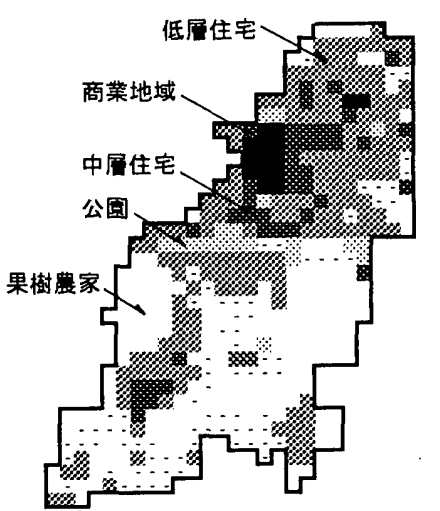

凡例

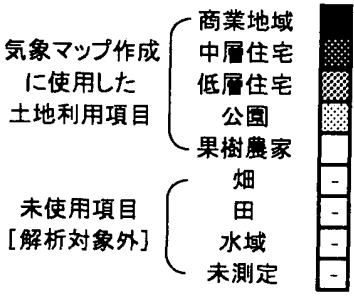

图一7 対象地域の土地利用 


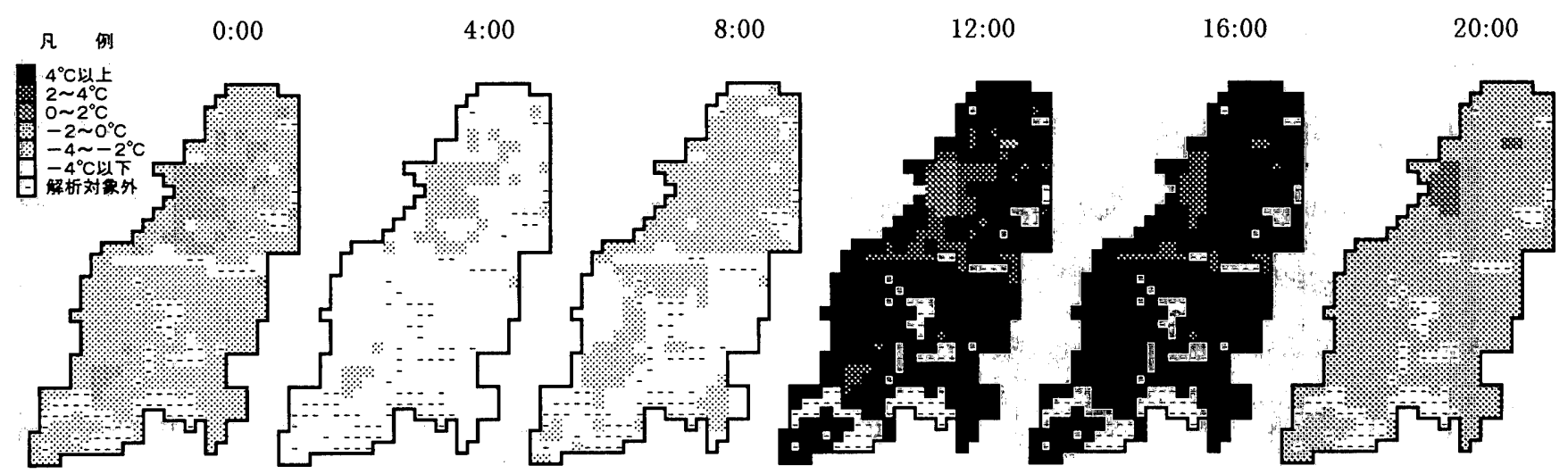

図ー8 最寒日の気温マップ

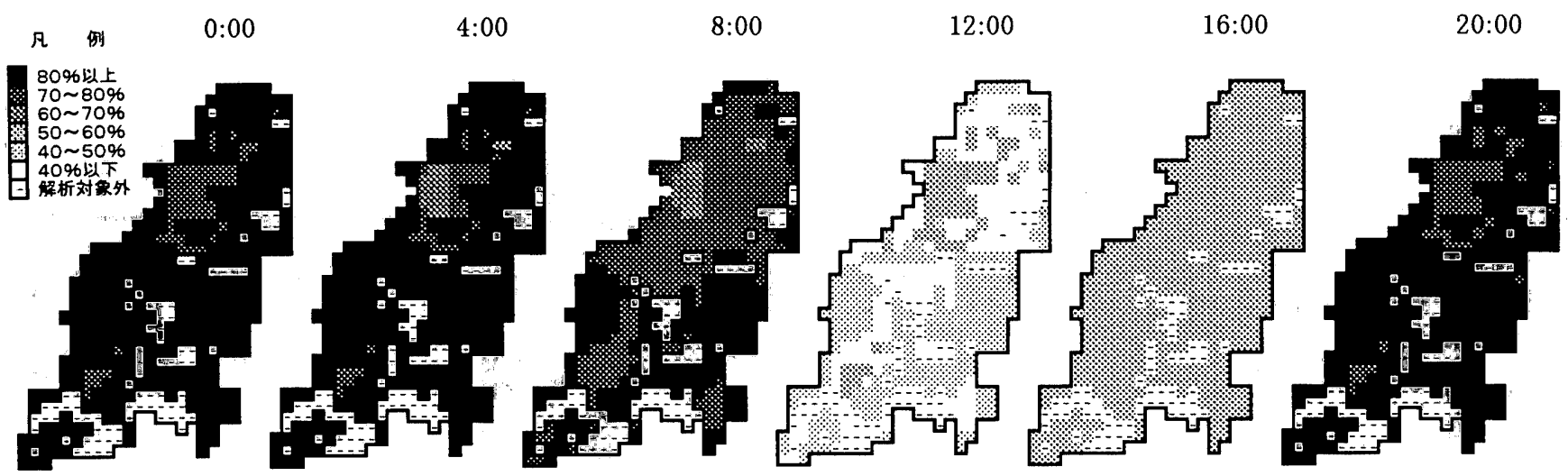

図一9 最寒日の相対湿度マップ

ータを用いた。なお、測定器と測定方法については 3 章と同様であ る。

代表点と検証点の概要を表ー 1 に示す。このうち、容栍率と建ぺ (率法都市計画図 ${ }^{2)}$ より、また建物率、敷地率、道路率は、測定点 を中心とする $500 \mathrm{~m}$ メッンんの面積率により示している。なお、面 積率は $1 / 2,500$ の国土基本図 $\left.{ }^{10}\right)$ を用い、建物、敷地、道路に区分 した紙を分析用電子天秤（最小表示：0.01mg）で計測し、その重量 比で表している。

図ー6に代表点と検証点における各実測値を、また表一 1 に $\mathrm{T}$ 一 検定の結果をそれぞれ示す。比較のため、既報 ${ }^{8)}$ で行った対象地域 内における同一の土地利用の検証の中から、低層住宅の結果を併せ て示す。共に信頼度 $95 \%$ で同一と判断されたものには○を、認めら れなかったものにはメを記している。

解析の結果、対象地域周囲では中野市の低層住宅の気温が代表点 と一致したが、それ以外のデータについては異なる結果となった。 この様な不一致の理由としては、地形による影響が考えられる。本 磁究で詨象とした長野市を中心とした地域は、約 $120 \mathrm{~km}^{2}$ の県内でも 比較的広い盆地であり、北西から東方向に $2 \%$ 以下の楥い勾配とな っている。これに対して、須坂市は逆に東から西方向へ最大 $5 \%$ の 傾斜である。また、飯山、更埴、戸倉、坂城は何れも平地部が比較 的狭く、周囲は 700 1,000mの山で覆われている。この様な地形の 違いにより、対象地域と対象地域周辺では風向風速、日照時問、日 射量、降水量などが異なり、気温や相対湿度についても同様の理由
により違いが生じたものと考える。

これに対し、対象地域内でば $\mathrm{t} 4$ "の相対湿度のデータ以外は一致 する事となった。一致の理由としては、対象地域内における地形の 類似があげられる。

従って、本論文では当初に設定した対象地域を研究対象とし、今 回実測を行った対象地域周囲については、気象が異なるため研究の 対象には含まない事とした。

\section{5. 気温、相対湿度の気象マップの作成 \\ 5.1 気争マップの作成条件}

対象地域において、気温と相対湿度の值は土地利用毎にほぼ一致 する事が分かったので、代表点の気象データと対象地域内の土地利 用を対応させ、気象マップを作成する事とした。その際、対象地域 内を500mメッシュで分割し、気象因子別に時系列での分布図をコン ピュータ処理により作成した。なお、気象マップ作成時の条件は次 の通りである。

(1)風向、風速など、他の気象因子の影響は考虑しない。

(2)各500mメッシュ内の土地利用はそれぞれ均一であると仮定する。 (3)土地利用として図一 7 を用いる。

(4)各代表点における 2 年問分のデータを使用する。

この内(1)は既報 ${ }^{8)}$ により、風向、風速は $100 \mathrm{~m}$ メシュより狭い範 囲で微気象が存在する事が明らかになっており、この様な気象因子 については考慮に入れない事とした。(2)は現地調查を主体に、また 


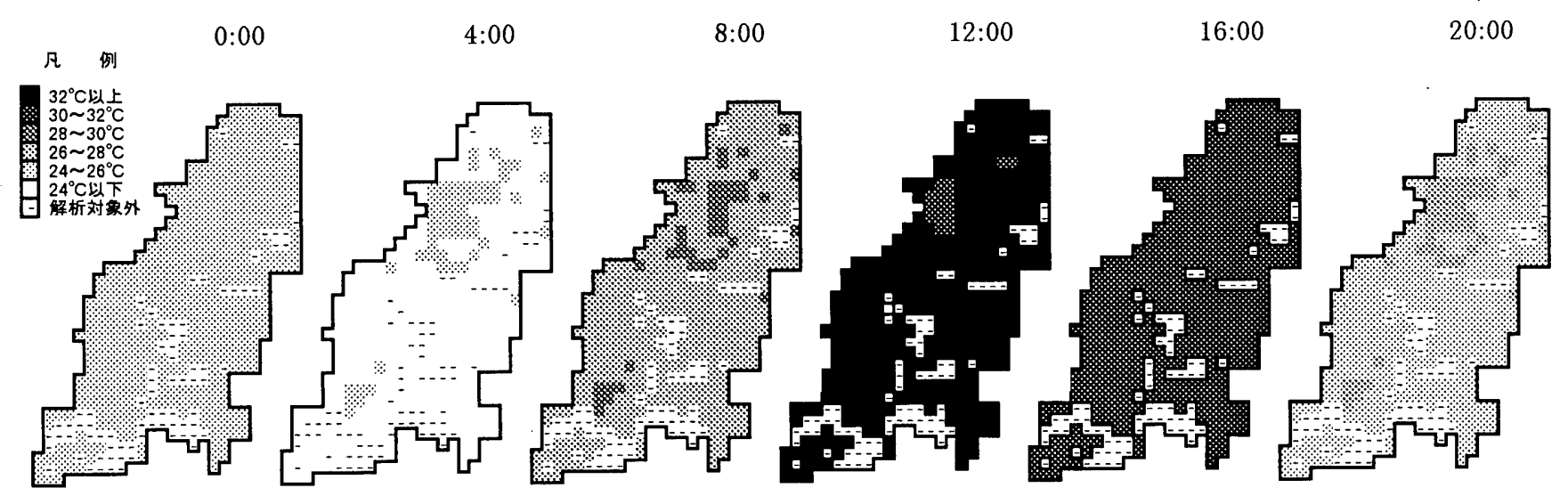

図ー10 最奢日の気温マップ

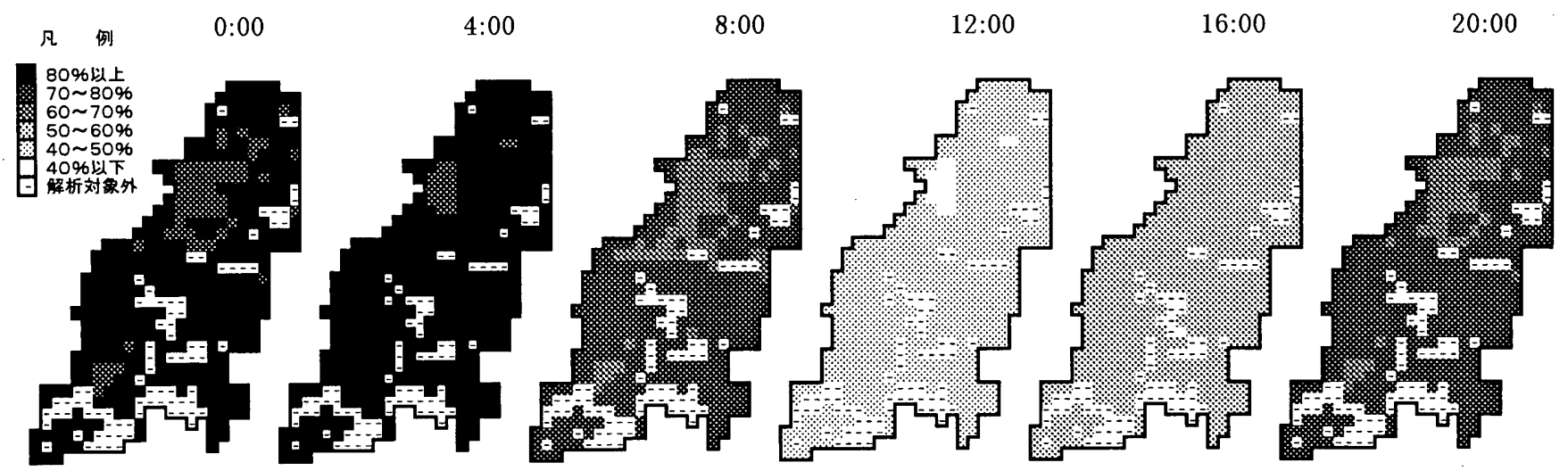

図一11 最暑日の相対湿度マップ

1/2,500の国土基本図 ${ }^{10)}$ を参考資料にして、メッシュ内の面積率 が60\%以上占めるものをその地点の土地利用とした。その際、国土 基本図からの読み取りについては、それぞれの地図記号が占める面 積を算出して判断した。また分類項目は、公園、商業、中層住宅、 低層住宅、果樹農家、水田、畑、水域の 8 項目を使用し、何れの土 地利用も60\%に満たない場合には“未測定”とし、解析の対象外とし た。(3)は、この内の連続測定を行っている5 項目（公園、商業、中 層住宅、低層住宅、果樹農家) を用い、図ー7 を作成した。なお、

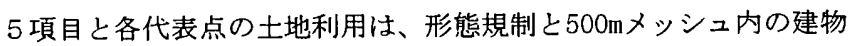
率、教地率、道路率の值が、全て同様であると仮定した。(4)は気温 と相対湿度の'96年12月 1 日より10分間隔でサンプリングしている 2 年間分のデータを用い、この値を同一の土地利用に対応させ、こ の期間における任意の季節、時間、天候の尺度で図を作成する事を 可能とした。

\section{2 最寒日と敢意日の気象マップ}

一例として、'97年における最寒日（1/10）と最暑日（8/2）の 気象マップを示す。作成した図は、何れも 1 日を 4 時間毎に区分し、 当該時間の前後10分問の平均值を用いている。な拉、両日は共に晴 天日で、対象地域のほぼ中央で観測した 1 日の平均風速と水平面全 天日射量の最大值は、最寒日が $1.2 \mathrm{~m} / \mathrm{s}$ と $1.9 \mathrm{MJ} / \mathrm{m}^{2}$ で、最暑日が $2.5 \mathrm{~m} /$ $\mathrm{s}$ と. $5 \mathrm{MJ} / \mathrm{m}^{2}$ であった。

最寒日の気温と相対湿度を図ー8と9にそれぞれ示す。

気温は、0:00には全体が $-4 \sim-2^{\circ} \mathrm{C}$ であのに対し、北部の商業

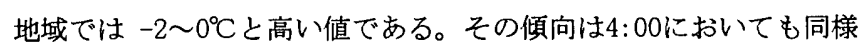
であるが、8:00には南部の果樹農家が他の地点より低くなる。12: 00 と16:00では、果樹農家と低層住宅の気温の上昇が顕著であり、 逆に商業地域は低くなる。また、20:00には0:00と同様に商業地域 の気温が高く、他の地点はそれより低い值である。

相対湿度は、20:00〜8:00の夜間から早朝にかけては、商業地域 では值が低いが、その周辺部では高くなっている。しかし、日中の 12:00には次第に商業地域の值が高くなり、16:00には地域全体の相 対湿度が等しくなる。

次に、最暑日の気温と相対湿度について図ー10と11に示す。

気温は、16:00 8:00の夕方から早朝にかけては、全体がほぼ同 様の值か、北部の商業地域で值が高い。しかし、日中12:00には他 の地域に比べて商業地域の值が低くなっている。この結果は、ヒ一 トアイランド現象の一般常識とは異なるが、その原因は中心商業地

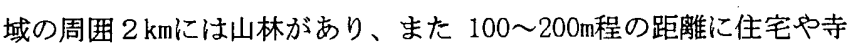
社の植生があるため、これらの影響によりヒートアイランド現象が 発生しにくいものと考える。また、商業地域とその周囲の地域では、 地上構案物の熱容量の違いも影響しているものと考える。

一方、石野ら ${ }^{71}$ は’ 78年〜'91年までの間の自治体の観測データと AMeDAS データを使用し、首都圈から $100 \mathrm{~km}$ 圈内の冬期と夏期の最 高気温と最低気温の分布を明らかにしている。これによると、首都 圈の気温は周囲の地域より最高気温と最低気温が共に高い傾向とな っている。また、この研究ではさらに J Rを利用した移動測定を行 
つており、東京駅を中心に取手や八王子など郊外までの気温分布を 剆定している。この結果においても冬期と夏期の両者で都心の気温 が高い傾向となっている。この様な大規模都市の実態に比べて、本 論文ではそれとは異なる結果となった。そのため、別途㜔しい実 測孝行い、長野市とそれと同規模の都市の気温の実態を明らかにす る事とした。

相対湿度は、16:00以外は商業地域が低く、また周囲が高い結果 となった。これは最寒日と同様の傾向となっている。

全体的には、北部の商業地域の気象変化が特徴的である。

\section{3 気象マップの誤差の検討}

前項において、気象マップの作成条件として500mメッシュ内の土 地利用が均一である事を仮定した。しかしながら、実際の環境では 複数の土地利用が混在する場合が見られ、実際に近い気象マップを 作成するためには、メッシュ内の土地利用を詳しく分析する必要が ある。そこで、各メッシュ内で2 番目に多い土地利用を調べ、その 面積率が20\%以上になる組合せを抽出した。調査の結果、表一 2 に 系我”ケース $\mathrm{a} \sim \mathrm{g}$ ”の 7 通りの組合せがある事が分かった。本論文 ऍは、この内の"ケース a,c,e,g”を対象に、2 番目に多い土地利用 がメッシュ内索100\%占めるものとし、作成した気象マップとの違 いを誤差として定義した。これは、解析対象の建物が 2 番目に多い 土地利用に該当する場合を想定している。即ち、気温と相対湿度の 知りたいポイントが、もし2番目の土地利用に含まれていた場合、 気象マップとの差がどの程度生じるかについて検討を行ったもので ある。この結果により作成した気象マップの、誤差の最大值が推定 できるものと考える。なお、“ケース b,d,f” の組合せについては、 それぞれ“ケース a,c,e” の土の反転により検討が可能である。

図一12と13に最寒日と最暑日の誤差をそれぞれ示す。

最寒日の気温は、誤差が大きいのは12:00の"ケース ース $\mathrm{g}$ ”の組合せで、平均值でそれぞれ $3.2^{\circ} \mathrm{C}$ と $4.6^{\circ} \mathrm{C}$ 差が生じて いる。同様に、最寒日の相対湿度においても"クース $\mathrm{g}$ "で誤差が大きく、その最大值は $14 \%$ となっている。

一方、最暑日では、気温の誴差は日中に多少生じるが、夜間は小 さい傾向である。また、相対湿度は"ケースc”の8:00どケース $\mathrm{g}$ "の夜間から早朝にかけて誤差が大きくなる。

この結果、気象マップの誤差は気温が $4.6^{\circ} \mathrm{C}$ 以下、相対湿度が 14 \%以下であり、最寒日の中層住宅が混在するケースで誤差が最も大 きくなる事が分かった。

\section{6. 地方都市における商業地域の気象}

\section{1 気温と建物表面温度の相関}

ここでは、5章で問題とした地方都市における商業地域の気温に

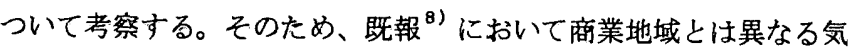
温分有となった低層住宅を取り上げ、同一日での比較を行った。ま た、それぞれの地域内において表面積の最も多く占める材料が都市 気候に影鄉を与えるものと考え、その表面温度についても併せて参 照する事とした。商業地域ではコンクリート壁面温度を、低層住宅 では表ー 1 の結果に従い地表面温度を参照した。これらの測定を行 った周囲の状況は、商業地域は図－4 (2)に示寸様に容積率が $600 \%$ で建ぺい率が80\%の地域で、6〜8階建てのコンクリート系建物が 多い。一方、低層住宅は図－44(4)とおり容積率が $80 \%$ で建ぺい率
表一

\begin{tabular}{|c|c|c|c|}
\hline \multirow[t]{2}{*}{ ケース } & \multicolumn{2}{|c|}{$\begin{array}{c}500 \mathrm{~m} \text { メシシュ內に占める } \\
\text { 土地利用の順位とその面積率 }\end{array}$} & \multirow{2}{*}{$\begin{array}{l}\text { 比率 } \\
{[\%]^{*}}\end{array}$} \\
\hline & 1 番 (60\%以上) & 2番 ( $20 \%$ 以上) & \\
\hline $\mathbf{a}$ & 果樹農家 & 低層住宅 & 4 \\
\hline$b$ & 低層住宅 & 果樹農家 & 2 \\
\hline c & 低層住宅 & 中層住宅 & 8 \\
\hline$d$ & 中層住宅 & 低層住宅 & 5 \\
\hline $\mathrm{e}$ & 中層住宅 & 商業地域 & 10 \\
\hline $\mathrm{f}$ & 商業地域 & 中層住宅 & 3 \\
\hline g & 果樹農家 & 中層住宅 & 5 \\
\hline
\end{tabular}

※ 全解析対象地点 ( 389 点) に対する比率

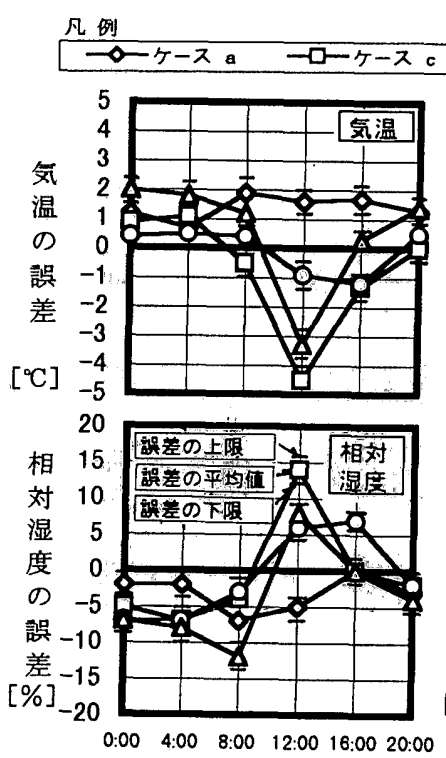

[時]

図一12 最寒日における誤差
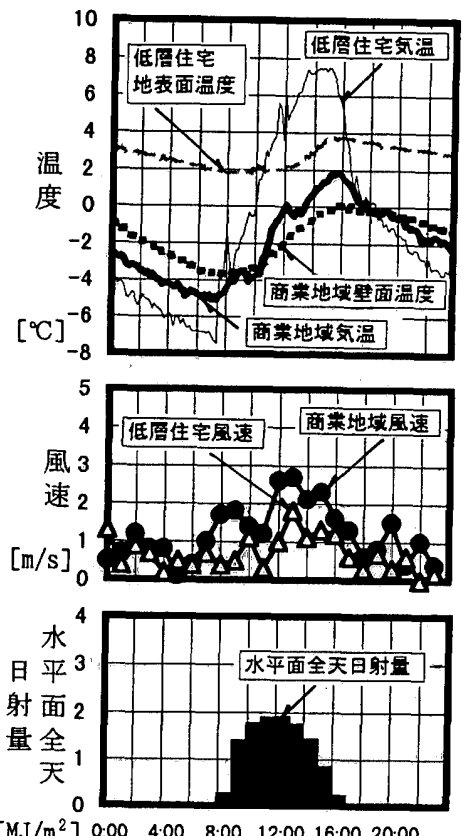

[時]

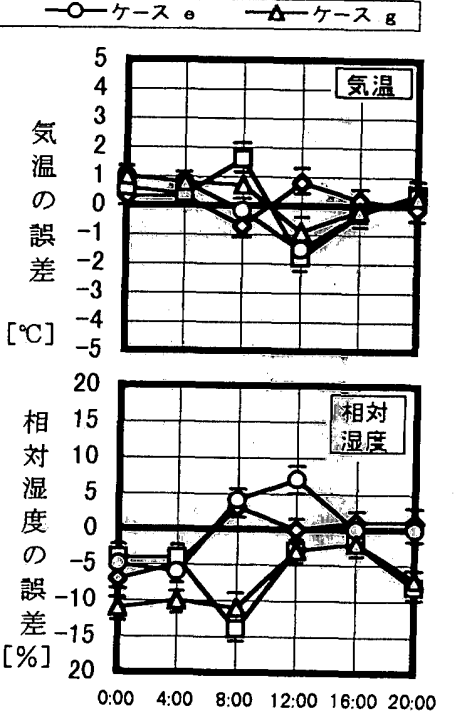

[時]

\section{図ー13最暑日における誤差}
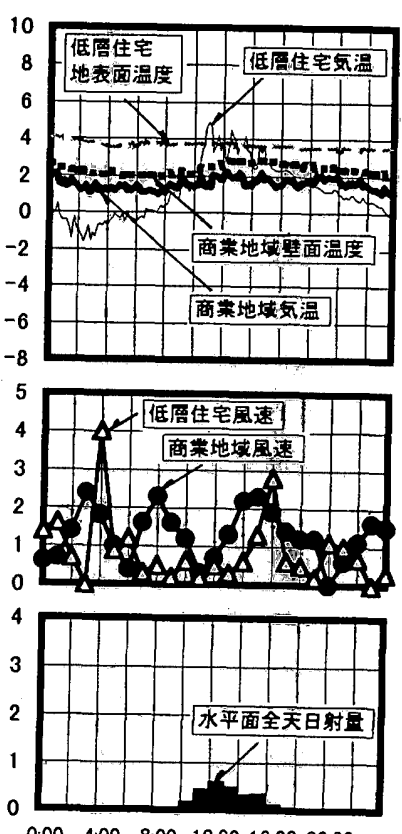

[時]

图一14 最寒日(晴天日)の 図-15 最寒日頃の不照日の 商業地域と低層住宅の気象状況 商業地域と低層住宅の気争状況 
が50\%の地域で、木造 2 階建てが主体である。そのため、商業地域 の方が熱容量が大きく、また天空率が小さい地域と言える。なお、 表面温度の実測は、何れも直射日光が当たらず、図中の気温の測定 点から $2 \mathrm{~m}$ 以内の地点とした。

図ー14に最寒日の事例として'97年 1 月 10 日の実態を示す。当日 は風速がほぼ静榣状態で、また水平面全天日射量が最大 $1.9 \mathrm{MJ} / \mathrm{m}^{2} の$ 晴天日であった。商業地域と低層住宅の気温を比較すると、日中は 低層住宅が高く、夜間は商業地域が高くなる。日中の気温について は既報 $^{8)}$ で示した様に、メッシュ内の建物、道路、敷地の各面檟率 や建物の建ぺい率、容積率が影響し、周辺に日影が多い商業地域は 低層住宅より低い值となる。また、低層住宅の気温と地表面温度の 関係に比べて、商業地域の気温と壁面温度は夜間に一定の差を保っ ているため相関が大きいと言える。一方、日射が周囲に当たる8:00 から17:00頃までは、気温が壁面温度より高くなっている。

次に、日射量が比較的少ない日の実測結果を参照する。図一15に 冬期の不照日の例として' 97 年 1 月 7 日の状況を示寸。当日は、風 速は晴天日と同様で、また水平面全天日射量は最大 $0.6 \mathrm{MJ} / \mathrm{m}^{2}$ の薷天 日である。低層住宅における気温と地表面温度については晴天日と 同様に相関が小さい。しかし商業地域を見ると、気温と壁面温度は 約0. $8^{\circ} \mathrm{C}$ の一定な差を保っている。この事から、日射の影響が少な い不照日の気温は、コンクリート壁面からの放熱が主な要因である と考える。

次に、最暑日の商業地域の気温について、最寒日と同様の検討を 行う。併せてその時の気象条件を図中に示す。図ー16は'97年 8 月 2 日の睛天日の例である。商業地域の気温と壁面温度は、夜間は両 者の值が一定の差を保っており、また日中は気温が壁面温度より高 くなっている。これは最寒日と同様の傾向である。

図一17の'97年 8 月 5 日の不照日についても確認すると、商業地 域の気温は終日壁面温度の影響を受けていると言える。

従って、これらの結果から長野市の商業地域の気温は、日射や建 物の表面からの放熱が主に関係している事が分かった。一方、交通 や産業からの廃熱の影響は比較的少ないと予想されるが、これにつ いては詳細な実測と解析が必要である。また、日中と夜間における 気温の分布は、長野市の商業地域では 5 章に示した様な石野ら゙に よる大規模都市の調查結果とは異なり、日中は低層住宅より低く、 また夜間は逆に高くなる事が明らかとなった。

\section{2 他の地方都市における商業地域の実態}

前項では、長野市の商業地域の気温の特性について明らかにした。 よって、この事が他の同規模の都市においても生じる現象であるか、 確認する必要がある。そのため、松本市を対象に長野市と同様の測 定を'98年 6 月より開始し、現在も測定を継続している。松本市は 長野県中部に位置し、’98年 6 月現在の人口が約20万人で、中心市 街地の規模が $2 \mathrm{~km}$ 四方程度である。よって、松本市は地理的にも人 口的にも長野市の実態と近似しており、商業地域の気温を検証する 上で有効であると判断した。図ー18に松本市の商業地域と、それと 比較するための低層住宅の測定点をそれぞれ示す。この内、両者の 形態規制については、図ー4の長野市の值とほぼ同様となっている。 なお、気温の測定は図中に示すの印の地点で行っており、また実測 方法については前記と同様の方法を用いている。

図一19に松本市に扔ける冬期の晴天日の例として、'98年11月26
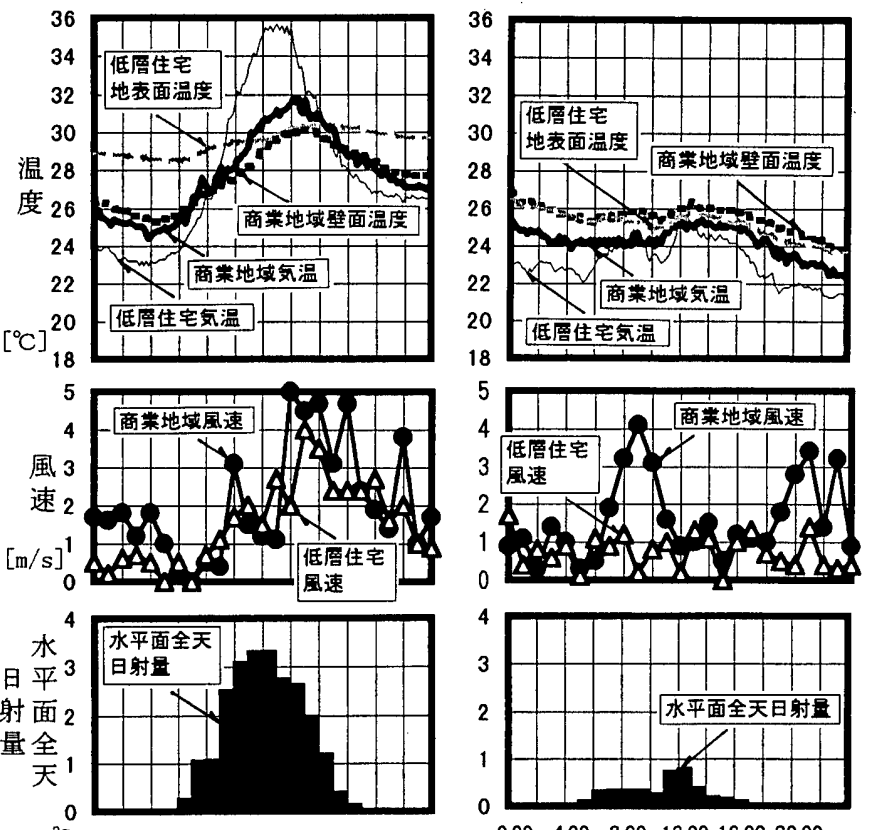

$\left[\mathrm{MJ} / \mathrm{m}^{2}\right] \quad 0: 00 \quad 4: 00 \quad 8: 00 \quad 12: 00 \quad 16: 00 \quad 20: 00$

[時]
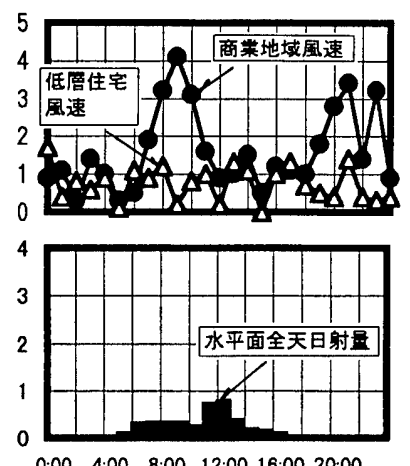

[時]

図ー16 最暑日(晴天日)の 図ー17 最暑日頃の不照日の 商業地域と低層住宅の気象状況 商業地域と低層住宅の気象状況
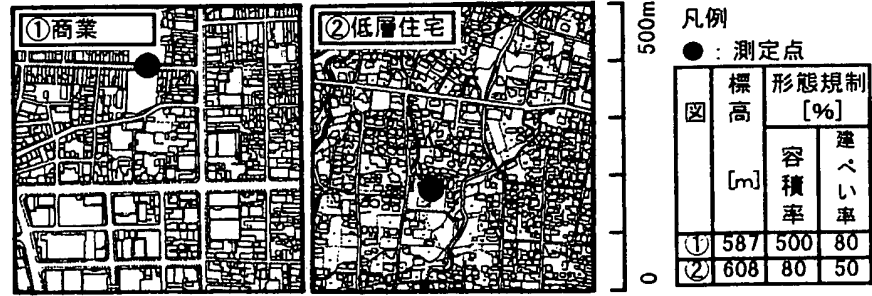

図-18 松本市における商業地域と低層住宅の測定点概要
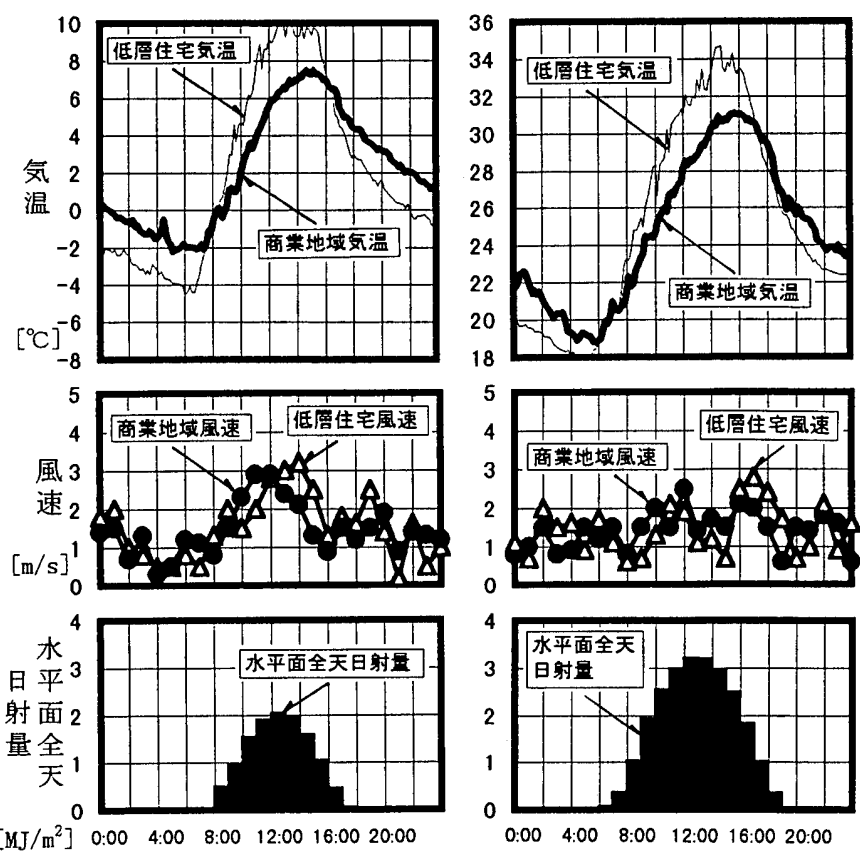

[時]

[時]

図一19 昖本市の冬期における 図一20 松本市の夏期における 商業地域と低層住宅の気温

商業地域と低層住宅の気温 
日を取り上げて両地域を比較する。当日の気象条件は、図中の通り 風速は共に平均 $1.5 \mathrm{~m} / \mathrm{s}$ 程度で、水平面全天日射量は最大 $2.1 \mathrm{MJ} / \mathrm{m}^{2}$ で ある。商業地域の気温は、夜間は低層住宅より平均で2. $2^{\circ} \mathrm{C}$ 高く、 また日中は最大で $2.5^{\circ} \mathrm{C}$ 低い值となっている。この要因は都市の規 模が長野市と同様である事から、松本市の商業地域も夜問は建物の 持つ熱容量が原因で放熱が行われ、日中は中高層の建物により日射 が遮られている事がその理由であると考える。

次に、図一20の夏期の晴天日である'98年8月23日の例を見ると、 商業地域恔低層住宅に比べ夜間は高く、また日中は低くなっており、 冬期と同様の傾向となっている。

従って、長野市における商業地域の気温の特性が松本市でも確認 する事ができ、これらの地方都市では大規模都市とは異なる気候に なる事が明らかとなった。

\section{7. まとめ}

長野市を対象に、500mメッシュ毎の実測データに基づく気象マッ プを作成し、都市気候の実態について検討を行ったところ、次に示 す結果が得られた。

(1) 対象地域周囲の実測值を T一検定し、同一の気温と相対湿度に なるエリアを明らかにする事ができた。

(2) 既報 ${ }^{8)}$ で得られた結果に基づいて、季節、時間、天候の尺度で 気象マップを作成する事が可能となった。また、一例として最寒日 と最暑日における気温と相対湿度の気象マップを作成した。

(3) 気象マップの誤差は気温が $4.6^{\circ} \mathrm{C}$ 以下、相対湿度が $14 \%$ 以下であ り、最寒日の中層住宅が混在するケースで誤差が最も大きくなる事 が明らかとなった。

(4)長野市の商業地域における気温の実態について検討したところ、 日射や建物からの放熱が主に関保している事が分かった。

(5)長野市における商業地域の気温の特性が、松本市でも確認する 事ができ、これらの都市では 5 章に示した石野ら゙による大規模都 市の実態とは異なる事が明らかとなった。

以上の結果、作成した気象マップや商業地域の気温の特性から、 地域内の都市気候の実態を知る事ができた。これらの結果は、建物 の熱負荷シミュレーション計算やパッシブ手法の検討を行う際の資 料として活用が可能であると考える。

今後は、対象地域におけるリモートセンシング技術を用いた気象
の解析や、他の都市における実測や解析を集積し、地方都市におけ る都市気候をさらに明らかにしていく予定である。

\section{䇏辞}

本研究を実施するにあたり、長野地方気象台、松本測候所、長野 県衛生公害研究所、長野市環境部に測定の衔協力をいただき、また 日射量と風向風速データの一部を提供いただいた。ここに記して感 謝の意を表します。

\section{参考文銤}

1)武政孝治, 小玉祐一郎:AMeDASデータに基づく建築設計用地域気候マップの 作成 (1) 気温、日射量、暖房度日による地域気候特性の表示, 日本建筑 学会大会学術講演梗概集, pp. 1017-1018,1992

2) 小丟祐一郎, 武政治: AMeDASテー夕に基づく建筑設計用地域気候マップの 作成 (2) PSP (パッシブ地域計数) による地域気候特性の表示, 白本建 築学会大会学術講演梗概集, pp. 1019-1020, 1992

3 ) 西川邦彦, 齐藤郁雄, 石原修: 自然エネルギーの活用のための気象データの 整備亡気候マップの作成, 日本建勧学会計画系論文報告集 第509号, pp. 1520,1998

4) 吉田治典: 気象データのモデル化と㻴境設計, 日本建築学会環境工学委員会, 熱環境小委員会第27回熱シンポジウム, pp. 49-58,1997

5) 永村悦子, 永村一雄: AMeDASデータの久测処理とその精度の確認（その1） 気温, 日本建筑学会大会学術講演梗概集, pp. 103-104,1997

6 ）二宫秀興，赤坂裕，松尾隄: AMeDASデータを用いた時系列大気放射量の推定 法, 空気調和衛生工学会 No. 60, pp. 133-134, 1996

7 ) 石野久滴, 郡公子, 谷本泪: 東京首都圈における架調設計用外気温度の分布 特性比関する研究, 日本建築学会計画系論文報告集第453号, pp. 1 17 -27, 1993

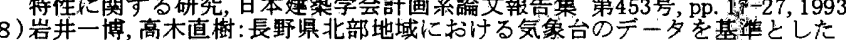
都市気候に関する研究, 日本建䓩学会計画系論文報告集 第516号, pp. 69-77,

9) 平成 8 年度長野都市㖕画図, 長野市都市計画課

10) $1: 2,500$ 長野国土基本図, 長野市, 1996

11）首藤治久,柇山順史,泉浩光,岡建雄:土地利用形態と気温形成に関する研究 旦本建勧学会計画采論文報告集第479号, pp. 49-56, 1996

12）首藤治久,程青, 横尾昇网, 岡建雄: 土地利用形態と気温形成に関市石研究 飞の 2 東海、東北及ひ閔東地域における解析結果とB值の考察, 昌本建築 学会計画系論文報告集 第497号, pp. 59-66, 1997

13)片山忠久, 石井昭夫, 西田勝, 堤純一郎, 森门明夫, 橋田光明:水面を有する市 街地の熱墂境に関守る調查研究, 日本建築学会計画系論文報告集 第372号, pp. 21-28, 1987

14）片山忠久，石井昭夫，西田勝，林徽夫，堤純一郎，㙁月羕隆，北山広榯，高山和安 大黒雅之:海岸都市における河川の嵵熱緩和効果に関守る調查研究, 日本建 学会部画系唋文報告焦第418号, pp. 1-9, 1990

15)村川云郎, 関根媇,成田健一,西名大作:都市内河川が周辺の温熱偯境に及ほ 寸効果に関する研究, 日本建築学会計画系論文報告集 第393号, pp. 25-34,

16) 中村泰人, 平岡久司, 西村浩一: 市街地空間における気温分布性状に関する実 筑的研究, 旦本建築学会計画系諭文報告集 第364号, pp. 48-55, 1986

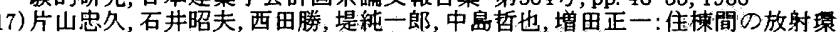

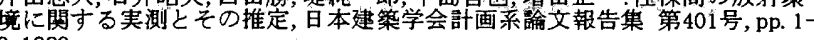
9,1989

18）石井昭夫, 片山忠久，塩月義隆，吉水久雅,阿部嘉孝:屋外気候噮境における快

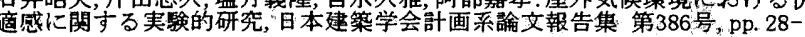
36,1988

19）渡辺浩文,依田浩敏, 尾岛俊雄: リモートセンシングデータと数值情報処理に 上る広域都市の地表面温度分布図の作成に関する研究, 日本建筑学会計画 系䜽文報告集 第443号, pp. 21-29, 1993

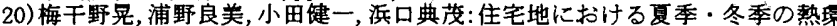
境実態りモートセンシングによる住宅地の熱環境の解析 (III), 日本建案学 会壾画系論 文報告集 第331号, pp. 38-44,1983

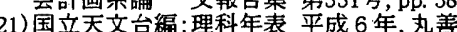

22) 良野県気像月報1996年-1998年, (財) 日本気象協会長野センター 